\title{
PERANAN PERUSAHAAN DALAM MENINGKATKAN KEMAMPUAN KERJA PETERNAK DAN KUALITAS HASIL PANEN MADU DI MASA PANDEMI
}

\section{Gusti Ayu Ari Agustini}

\author{
Politeknik Internasional Bali \\ email: ari.agustini@pib.ac.id
}

\begin{abstract}
ABSTRAK
Pandemi Covid-19 tidak dimungkiri telah melumpuhkan perekonomian masyarakat luas. Usaha peternakan lebah dan turunannya menjadi salah satu usaha yang cukup menjanjikan di masa pandemi saat ini. Madu yang merupakan salah satu dari produk turunannya sudah menjadi kebutuhan yang paling diminati masyarakat untuk menjaga stamina dan daya tahan tubuh. Saat ini permintaan pasar akan madu dengan kualitas baik semakin besar, sehingga peluang tersebut banyak dimanfaatkan oleh pelaku usaha madu. Tujuan penelitian ini adalah menganalisis upaya yang dilakukan Bali Honey dalam meningkatkan kemampuan kerja peternak madu di tengah pandemi covid-19 dan menganalisis strategi yang dilakukan untuk meningkatkan kualitas hasil panen madu agar membawa manfaat bagi masyarakat setempat. Metode analisis data adalah deskriptif kualitatif. Dalam melakukan analisis data dilakukan dengan mengumpulkan data sekunder maupun data primer. Data serta informasi yang diperoleh melalui penelitian lapangan kemudian dianalisis dengan melakukan reduksi data yaitu meringkas data hasil wawancara dan observasi lapangan, kemudian saling dikaitkan dengan landasan teori dan kajian pustaka untuk mendapatkan kesimpulan final. Landasan teori yang digunakan dalam penelitian yaitu teori penguat, teori harapan, dan teori penetapan tujuan. Hasil penelitian yaitu edukasi konsisten yang dilaksanakan Bali Honey berperanan penting dalam meningkatkan kemampuan kerja peternak madu sehingga kualitas hasil panen yang dihasilkan dapat bersaing di pasaran.

Kata Kunci: peranan perusahaan, kemampuan kerja, kualitas produk
\end{abstract}

\section{ABSTRACT}

The Covid-19 pandemic has undeniably crippled the economy of the wider community. Beekeeping and its derivatives business are promising efforts during the current pandemic. Honey, which is one of its derivative products, has become a necessity that is most in demand by the public to maintain stamina and endurance. Currently the market demand for good quality honey is getting bigger, so that this opportunity is widely exploited by honey business actors. The purpose of this study was to analyze the efforts made by Bali Honey in improving the working ability of honey breeders in the midst of the Covid-19 pandemic and to analyze the strategies implemented to improve the quality of the honey harvest to bring benefits to the local community. The data analysis method is descriptive qualitative. Data analysis was carried out by collecting secondary data and primary data. The data and information obtained through field research are then analyzed by doing data reduction, namely summarizing the data from interviews and field observations, then interlinking them with the theoretical basis and literature review to get a final conclusion. The theoretical foundations used in the research are reinforcement theory, expectancy theory, and goal setting theory. The result of the research is that consistent education carried out by Bali Honey plays an important role in improving the working ability of honey farmers so that the quality of the yields produced can compete in the market.

Keyword: the role of the company, work ability, product quality 


\section{PENDAHULUAN}

Pandemi covid-19 tidak selamanya merugikan, namun juga memiliki dampak positif terutama bagi peternak lebah madu yang ada di Pulau Bali. Setelah hampir 5 bulan virus Corona mewabah di Indonesia, usaha peternakan lebah madu mampu meningkatkan penjualan dengan cukup signifikan hingga 100 persen. Madu merupakan salah satu makanan tambahan yang banyak digemari masyarakat. Selain karena rasanya yang manis, juga memiliki manfaat yang baik untuk kesehatan, sehingga madu memberikan peluang usaha yang cukup menjanjikan, baik bagi peternak maupun penjualnya. Peluang tersebut dapat dilihat dari adanya jumlah permintaan terhadap produk madu yang semakin meningkat setiap tahun. Begitu juga dengan yang dirasakan oleh Ismail, selaku pemilik usaha madu di Bali dengan brand 'Bali Honey', peningkatan permintaan madu oleh konsumen di masa pandemi ini dikatakan cukup signifikan. Bermula dari komitmen untuk menjalankan visi perusahaan yaitu menjadi panutan penyedia produk perlebahan kualitas terbaik dengan pola penanganan yang mengedepankan keseimbangan manusia dengan alam serta fair trade business, Bali Honey, dengan strategi usahanya ingin merangkul semua pihak stake holders mulai dari pemerintah sebagai penguasa hutan, petani komoditas, para ahli, dan pencari madu serta pemelihara lebah sampai pebisnis korporasi untuk menghasilkan dan mempromosikan sekaligus memperdagangkan produk hasil perlebahan Indonesia dengan kualitas standar mutu internasional dengan tetap melestarikan alam. Bali Honey dalam mendukung kesehatan di masa pandemi ini menyediakan madu dengan kualitas dan harga yang terjangkau sehingga banyak orang dapat mengkonsumsinya sebagai daya tahan tubuh.

Kendala yang masih ditemukan saat ini yaitu masih banyak pencari madu dan peternak lebah belum menjalankan kegiatan usahanya sesuai dengan prosedur yang seharusnya, sehingga hasil panen madu yang ditawarkan selalu berubah tidak terstandar. Hal ini diperburuk dengan berkurangnya kuantitas flora Indonesia dan tingginya pemakaian bahan kimia yang berdampak pada harga madu makin tinggi yang akhirnya membuka peluang beredarnya madu dengan mutu rendah, serta tingkat konsumsi madu dan produk perlebahan di Indonesia menjadi sangat rendah. Disisi lain, pengetahuan konsumen tentang madu juga minim sehingga mudah mempercayai mitos dan pendapat non ilmiah. Melihat kelemahan tersebut Bali Honey ingin benar-benar dapat meningkatkan peranannya dalam upaya meningkatkan kualitas hasil panen madu khususnya di Bali dan Indonesia. Untuk menjamin dan mendukung kualitas produk yang dihasilkan, saat ini Bali Honey bersama rekannya sedang mempersiapkan pengelolaan madu dengan standard mutu bertaraf internasional ISO 9001:2015 yaitu sertifikasi sistem manajemen mutu yang biasa disebut juga sertifikasi sistem manajemen kualitas. Tujuan sertifikasi ini adalah untuk dapat menjamin produk madu yang dihasilkan perusahaan Bali Honey memenuhi syarat-syarat yang menjadi ketetapan badan standar dunia yaitu ISO (International Organization for Standardization atau Organisasi Standar Internasional). Ketika perusahaan Bali Honey nantinya telah berhasil lulus audit dan mendapatkan ISO 90012015 , artinya Bali Honey telah memenuhi berbagai persyaratan yang telah ditetapkan secara internasional. Bila perusahaan Bali Honey dapat memenuhi kebutuhan 
konsumennya secara jelas dan spesifik, maka dapat dikatakan bahwa perusahaan Bali Honey dapat bertanggung jawab dengan jaminan kualitas dari produk madu yang dihasilkan. Berdasarkan gambaran sebagaimana telah diuraikan di atas maka penulis merumuskan masalah sebagai berikut: Apakah upaya yang telah dilakukan Perusahaan Bali Honey dalam meningkatan kemampuan kerja peternak madu di masa pandemi covid-19? dan Bagaimanakah strategi yang dilakukan untuk meningkatkan kualitas hasil panen madu agar dapat membawa manfaat bagi peternak madu, pemilik kebun dan juga masyarakat setempat? Tujuan yang hendak dicapai penulis pada penelitian ini yaitu untuk menganalisis upaya yang dilakukan dalam meningkatan kemampuan kerja peternak madu di tengah pandemi covid-19 dan menganalisis strategi yang dilakukan untuk meningkatkan kualitas hasil panen madu agar dapat membawa manfaat bagi masyarakat setempat

Peranan adalah tindakan yang dilakukan seseorang dalam suatu peristiwa. (Kamus Besar Bahasa Indonesi (Online). Peranan juga diartikan sebagai tindakan yang dilakukan oleh seseorang atau beberapa orang dalam sebuah peristiwa, juga diartikan sebagai sebuah perangkat dari tingkah laku yang diinginkan dan yang dimiliki oleh orang atau seseorang di tengah masyarakat. Untuk kepentingan pengetahuan, kedudukan dan peranan tidak dapat dipisahkan satu sama lain, keduanya saling menunjang satu sama lain. Menurut Soerjono Soekanto, "peranan adalah aspek dinamis kedudukan. Seseorang yang telah melaksanakan hak dan kewajiban sesuai dengan kedudukannya disebut telah menjalankan suatu peranan (Soekartiko, 2000). Berdasarkan penjelasan di atas diketahui bahwa setiap individu atau organisasi termasuk Perusahaan Bali Honey, menjalankan peranan sesuai dengan posisi perusahaan dalam masyarakat. Bali Honey dalam menjalankan perannya mewajibkan SDM untuk terlebih dahulu terlatih sesuai standar yang ada dan SDM mempunyai hasrat untuk melaksanakan kegiatan panen madu dengan cara yang telah ditentukan. Setelah itu Bali Honey baru dapat melakukan bimbingan kepada seseorang atau sekelompok orang terkait kegiatan panen madu yang baik dan benar.

Pengertian kemampuan menurut Simamora (2006), "Kemampuan merupakan salah satu unsur dalam kematangan yang berkaitan dengan pengetahuan dan ketrampilan yang dapat diperoleh dari pendidikan, pelatihan, dan suatu pengalaman". Kemampuan berhubungan erat dengan kemampuan fisik dan mental yang dimiliki oleh seseorang untuk melaksanakan pekerjaan dan bukan yang ingin dilakukannya. Menurut Robbins \& Judge (2008), kemampuan adalah suatu kapasitas individu untuk mengerjakan berbagai tugas dalam suatu pekerjaan. Kemampuan merupakan potensi yang ada dalam diri seseorang untuk berbuat sehingga memungkinkan seseorang untuk dapat melakukan pekerjaan ataupun tidak dapat melakukan pekerjaan tersebut.

Menurut Kamizal (2015) menyatakan bahwa, "Kemampuan (ability) sama dengan pengetahuan dan keterampilan (knowledge dan skill)". Menurut Robbins \& Judge (2008) menyatakan bahwa kemampuan terdiri dari dua faktor, yaitu: (a) Kemampuan intelektual (intelectual ability) merupakan kemampuan melakukan aktivitas secara mental. (b) Kemampuan fisik (physical ability) merupakan 
kemampuan melakukan aktivitas berdasarkan stamina kekuatan dan karakteristik fisik.

Kemampuan kerja merupakan suatu keadaan yang ada pada diri pekerja yang secara sungguh-sungguh berdaya guna dan berhasil guna dalam bekerja sesuai bidang pekerjaannya. Kemampuan kerja mengacu kepada beberapa indikator yaitu: (1) Kemampuan teknis, dengan sub-sub indikator penguasaan terhadap peralatan kerja dan sistem komputer, penguasaan terhadap prosedur dan metode kerja, memahami peraturan tugas atau pekerjaan. (2) Kemampuan konseptual dengan sub-sub indikator memahami kebijakan perusahaan, memahami tujuan perusahaan, memahami target perusahaan. (3) Kemampuan sosial dengan sub-sub indikator mampu bekerjasama dengan teman tanpa konflik, kemampuan untuk bekerja dalam tim, kemampuan untuk berempati.

Indikator kemampuan kerja menurut Robbins \& Judge (2008) terdiri dari : (a) Produktifitas kerja meliputi (kemampuan menyelesaikan pekerjaan dengan baik, berkonsentrasi sangat diperlukan dalam menyelesaikan perkerjaan). (b) Pengetahuan meliputi (pendidikan formal, dapat berfikir cepat untuk memecahkan masalah pekerjaan. (c) Keterampilan meliputi (cepat beradaptasi dan berinteraksi di lingkungan kerja, melakukan pekerjaan teliti dan rapi, kemampuan menguasai pekerjaan).

Berdasarkan pengertian di atas dapat disimpulkan bahwa kemampuan kerja merupakan faktor utama lainnya yang mempengaruhi kualitas hasil panen madu. Kemampuan kerja harus dirancang, dibangun dan dikelola secara profesional sehingga dapat menjaga sekaligus meningkatkan hasil kualitas panen.

Kotler dan Keller (2017) menyebutkan bahwa kualitas produk adalah kumpulan ciri-ciri karakteristik barang dan jasa yang memiliki kemampuan untuk memenuhi kebutuhan yang merupakan suatu pengertian dari gabungan daya tahan, keandalan, ketepatan, kemudahan dalam pemeliharaan serta atribut lainnya dari suatu produk. Produk merupakan segala sesuatu yang dapat diperdagangkan dengan tujuan memuaskan keinginan atau kebutuhan konsumen, (Kotler dan Keller, 2017). Kualitas produk dilihat dari adanya kecocokan penggunaan produk (fitness for use) dalam memenuhi kebutuhan dan kepuasan konsumen, Juran dalam (Nasution, 2005). Kualitas produk juga merupakan suatu kondisi dinamis yang berhubungan dengan produk, sumber daya manusia, proses dan tugas, serta lingkungan yang memenuhi atau melebihi harapan konsumen. Tjiptono (2015) menyebutkan bahwa kualitas sebagai tingkat mutu yang diharapkan dimana pengendalian keragaman dalam mencapai mutu adalah untuk memenuhi kebutuhan konsumen. Menurut Kotler \& Gary Amstrong (2018), kualitas produk merupakan kemampuan suatu produk dalam melaksanakan fungsinya, antara lain daya tahan, kemudahan operasi, kehandalan, perbaikan, dan atribut nilai. Berdasarkan beberapa definisi di atas diketahui bahwa kualitas hasil panen madu Bali Honey memenuhi keinginan konsumen, konsumen merasa cocok dengan produk yang dihasilkan Bali Honey atau sesuai dengan keinginan yang diharapkan untuk memenuhi kebutuhan konsumen. Keinginan konsumen tersebut diantaranya daya tahan produk, keandalan produk, kemudahan pemakaian, serta atribut bernilai lainnya yang bebas dari kekurangan dan kerusakan. 
Perusahaan selalu menginginkan hasil kerja terbaik dari pegawainya sehingga perusahaan akan berusaha memotivasi para pekerjanya. Banyak cara yang dapat dilakukan untuk memotivasi para pekerja sehingga kemampuan kerja para pegawai semakin meningkat. Seperti dengan teori penguat, untuk memotivasi para pekerja mengulangi perilaku yang dikehendaki perusahaan dengan reward sebagai hasilnya. Teori harapan yang digunakan untuk meningkatkan kemampuan kerja pegawai sesuai dengan harapan apa yang ingin diraih. Teori tujuan berfungsi untuk meningkatkan kemampuan kerja dengan memberikan tujuan yang lebih kompleks agar pegawai lebih maksimal memberikan kemampuannya dalam sebuah bidang.

Teori Penguat (Reinforcement Theory)

Teori ini dikemukakan oleh Burrhus Frederic Skinner pada Tahun 1953. Skinner adalah seorang ahli psikologi dunia yang lahir pada tanggal 20 maret 1904 di kota Susquenhanna, Pennshyilvania, AS. Teori Penguat didasarkan atas "hukum pengaruh". Tingkah laku dengan konsekuensi positif cenderung untuk diulang, sementara tingkah laku dengan konsekuensi negatif cenderung untuk tidak diulang. Rangsangan yang didapat akan mengakibatkan atau memotivasi timbulnya respon dari seseorang yang selanjutnya akan menghasilkan suatu konsekuensi yang akan berpengaruh pada tindakan selanjutnya. Konsekuensi yang terjadi secara berkesinambungan akan menjadi suatu rangsangan yang perlu untuk direspon kembali dan menghasilkan konsekuensi lagi. Demikian seterusnya sehingga motivasi peternak madu dapat tetap terjaga untuk menghasilkan hal-hal yang positif.

Teori ini dikemukakan oleh Victor H. Vroom pada tahun 1964, yang mengatakan bahwa seseorang bekerja untuk merealisasikan harapan-harapannya dari pekerjaan yang dilakukan. Teori ini menunjukkan bahwa kekuatan dari suatu kecenderungan untuk bertindak dalam cara tertentu bergantung pada kekuatan dari suatu harapan bahwa tindakan tersebut akan diikuti dengan hasil yang ada dan pada daya tarik dari hasil itu terhadap individu tersebut. Teori ini berusaha agar setiap pekerja mau bekerja giat sesuai dengan harapan. Daya penggerak yang memotivasi semangat kerja terkandung dari harapan yang akan diperolehnya. Jika harapan menjadi kenyataan maka pekerja cenderung akan meningkatkan kualitas kerjanya, begitu pula sebaliknya.

Teori ini didasarkan kepada tiga komponen, yaitu : (a) Harapan adalah suatu kesempatan yang disediakan dan akan terjadi karena perilaku. (b) Nilai (Valence) merupakan nilai yang diakibatkan oleh perilaku tertentu. Misalnya nilai positif pada peristiwa terpilihnya seseorang karena memang ingin dipilih, nilai negatif bila seseorang kecewa karena sebenarnya tidak ingin dipilih serta acuh tak acuh jika bernilai nol. (c) Pertautan (nstrumentality).

Besarnya probalitas jika bekerja secara efektif apakah akan terpenuhi keinginan dan kebutuhan tertentu yang diharapkannya.Teori ini berfokus pada tiga hubungan : (a) Hubungan usaha-kerja, kemungkinan yang dirasakan oleh individu yang mengeluarkan sejumlah usaha akan menghasilkan kinerja. (b) Hubungan kinerja-penghargaan, tingkat sampai mana individu tersebut yakin bahwa bekerja pada tingkat tertentu akan menghasilkan pencapaian yang diinginkan. (c) 
Hubungan penghargaan-tujuan pribadi, tingkat sampai mana penghargaanpenghargaan organisasional memuaskan tujuan-tujuan pribadi seorang individu.

Penelitian ini menggunakan pendekatan Goal Setting Theory yang dikemukakan oleh Edwin Locke pada akhir tahun 1960. Edwin Locke menemukan bahwa tujuan spesifik dan sulit menyebabkan kinerja tugas lebih baik dari tujuan yang mudah. Goal setting theory didasarkan pada bukti yang berasumsi bahwa sasaran (ide-ide akan masa depan atau keadaan yang diinginkan) memainkan peran penting dalam bertindak.

Edwin Locke mengemukakan bahwa dalam penetapan tujuan memiliki empat macam mekanisme motivasional yakni: (a) Tujuan-tujuan mengarahkan perhatian; (b) Tujuan-tujuan mengatur upaya; (c) Tujuan-tujuan meningkatkan persistensi; dan (d) Tujuan-tujuan menunjang strategi dan rencana kegiatan.

Teori penetapan tujuan juga mengungkapkan hal-hal sebagai berikut: (a) Kuat lemahnya tingkah laku manusia ditentukan oleh sifat tujuan yang hendak dicapai. (b) Kecenderungan manusia untuk berjuang lebih keras mencapai suatu tujuan, apabila tujuan itu jelas, dipahami dan bermanfaat. (c) Makin kabur atau makin sulit dipahami suatu tujuan, akan makin besar keengganan untuk bertingkah laku.

Menurut teori penetapan tujuan salah satu dari karakteristik perilaku yang mempunyai tujuan yang umum diamati adalah perilaku tersebut terus berlangsung sampai perilaku itu mencapai penyelesaiannya, sekali seseorang mulai sesuatu (seperti suatu pekerjaan, sebuah proyek baru), maka akan terus mendesak sampai tujuan tercapai. Teori ini juga menyatakan bahwa perilaku individu diatur oleh ide (pemikiran) dan niat seseorang. Sasaran dapat dipandang sebagai tujuan atau tingkat kerja yang ingin dicapai oleh individu. Niat untuk mencapai sebuah tujuan merupakan sumber motivasi kerja yang utama. Artinya tujuan memberi tahu seorang karyawan apa yang harus dilakukan dan berapa banyak usaha yang harus dikeluarkan. Kesimpulannya, bahwa penetapan suatu tujuan tidak hanya berpengaruh terhadap pekerjaan saja, tetapi juga mempengaruhi orang tersebut untuk mencari cara yang efektif dalam mengerjakannya. Kejelasan tujuan yang hendak dicapai oleh seseorang dalam melaksanakan tugasnya akan menumbuhkan motivasi yang tinggi. Tujuan yang sulit sekalipun apabila ditetapkan sendiri oleh orang yang bersangkutan atau organisasi yang membawahinya akan membuat prestasi yang meningkatkan, asalkan dapat diterima sebagai tujuan yang pantas dan layak dicapai.

Beberapa hasil penelitian sebelumnya yang dianggap relevan dengan penelitian ini antara lain, penelitian yang dilakukan oleh Azhari Wispinaldo (2016), yang berjudul Peranan Kelompok Tani dalam Pemanfaatan Madu Lebah Hutan Di Desa Sahilan Darussalam Kecamatan Gunung Sahilan Kabupaten Kampar Provinsi Riau. Penelitian yang dipaparkan secara deskriptif kualitatif ini bertujuan untuk mengetahui peranan kelompok tani dalam pemanfaatan madu lebah hutan di Desa Sahilan Darussalam Kecamatan Gunung Sahilan Kabupaten Kampar Provinsi Riau. Hasil penelitian menunjukkan bahwa peranan kelompok tani yaitu peran dalam kelembagaan, produksi, dan modal. Peran kelompok tani dalam bidang kelembagaan yaitu meningkatkan pendapatan perbulan dan mudah mengikuti program-program pengembangan madu hutan yang didukung 
pemerintah. Peran kelompok tani bidang produksi dalam menjaga kualitas kegiatan kualitas kegiatan produksi yaitu dengan melakukan sistem tiris. Peran kelompok tani dalam bidang modal yaitu kelompok tani mendapatkan modal utama secara swadaya dari anggota. Penelitian ini mendukung karena sama-sama mengungkapkan keterlibatan peran kelompok atau organisasi dalam aktivitasnya. Perbedaannya terletak pada fokus penelitian yang akan dilakukan, penelitian ini memaparkan lebih dalam terkait proses beternak dan panen madu yang baik dan benar dalam upayanya meningkatkan kualitas hasil panen.

Penelitian kedua berjudul Usaha Ternak Lebah Madu dan Faktor-Faktor yang mempengaruhi Produksi Madu di Desa Lolu Kabupaten Sigi Provinsi Sulawesi Tengah oleh Alma (2018). Penelitian ini dipaparkan dengan metode deskriptif dan kuantitatif berangkat dari teori menuju data. Tujuannya untuk mengetahui faktor-faktor yang mempengaruhi produksi ternak lebah madu yang dilakukan. Hasil penelitian menunjukkan bahwa secara keseluruhan, variabel jumlah sarang atau stup, jumlah tenaga kerja dan pengalaman beternak lebah madu berpengaruh sangat nyata terhadap produksi usaha ternak lebah madu. Penelitian ini dijadikan referensi karena serupa dengan penelitian penulis yang membahas mengenai kemampuan kerja peternak madu dan kualitas hasil panen. Perbedaannya pada tujuan penelitian yaitu membahas tentang upaya yang dilakukan untuk meningkatkan kemampuan kerja peternak madu.

Penelitian ketiga berjudul Budidaya Lebah Madu Apis Mellifera oleh Masyarakat Pedesaan Kabupaten Pati, Jawa Tengah oleh Farida (2000). Penelitian ini berupaya untuk mendapatkan informasi budidaya lebah madu A. Mellifera yang dikembangkan masyarakat, permasalahan yang muncul, serta solusinya. Penelitian tersebut dilakukan secara deskriptif kualitatif, dengan sampel penelitian populasi peternak lebah di Kecamatan Gembong. Hasil penelitian ini mengungkapkan bahwa ada enam kategori permasalahan dalam budidaya lebah madu Apis Mellifera yaitu persoalan pakan, dana, penyuluhan, pembinaan teknis sdm, bibit/induk ratu, dan hama. Dari hasil tersebut diketahui bahwa ketersediaan sumber pakan merupakan masalah utama dalam budidaya lebah madu. Perbedaan terletak pada tujuan penelitian dimana penelitian ini bertujuan untuk melakukan pembinaan terhadap para peternak madu agar memiliki kemampuan kerja yang baik dan benar sebagai upaya meningkatkan kualitas hasil panen madu.

\section{METODE PENELITIAN}

Metode penelitian diartikan sebagai cara ilmiah untuk mendapatkan data yang valid dengan tujuan dapat ditemukan, dikembangkan, dan dibuktikan, sehingga dapat digunakan untuk memahami, memecahkan, dan mengantisispasi masalah (Sugiyono, 2017). Metode penelitian meliputi prosedur dan teknik penelitian. Sebelum dilakukan penelitian, disiapkan rancangan penelitian dengan cakupan komponen yang diperlukan. Menurut Sugiyono (2017) metode deskriptif adalah metode yang digunakan untuk menggambarkan atau menganalisis suatu hasil melalui pengamatan atau observasi, wawancara dan studi dokumentasi, baik terhadap peternak lebah madu, petani buah dan bunga maupun masyarakat lokal dan umum, mengenai kegiatan panen madu, selanjutnya hasil kumpulan pendapat 
informan tersebut yang berupa data akan dipaparkan dengan menggunakan metode desriptif kualitatif. Penelitian ini bertujuan untuk mendapat gambaran dan informasi yang lebih jelas, lengkap, serta memungkinkan dan mudah bagi peneliti untuk melakukan penelitian observasi. Adapun Informan yang dipilih dikelompokan kedalam beberapa kategori, 1. Perusahaan: Direktur/ pemilik usaha Bali Honey, 2. Peternak/Pemelihara Lebah: Pekerja yang melakukan kegiatan panen madu, 3. Pemilik Lahan Kebun tempat dilakukannya panen madu, 4. Masyarakat Umum.

Lokasi penelitian adalah tempat di mana penelitian akan dilakukan. Lokasi penelitian yaitu di kantor pusat Bali Honey Jl. By Pass Ngurah Rai, Ruko Griya Sanur No. 37, Kota Denpasar, Bali 80117, dan di area panen madu di Desa Kubu, Karangasem, Bali. Penentuan informan pada penelitian ini dilakukan dengan teknik purposive sampling. Pemilihan dilakukan secara sengaja berdasarkan kriteria yang telah ditentukan dan ditetapkan berdasarkan tujuan penelitian. Adapun kriteria informan yang ditunjuk atau dipilih dalam penelitian ini adalah informan yang mengetahui tentang kegiatan panen madu yang berada di sekitar area panen, dan masyarakat umum.

\section{HASIL DAN PEMBAHASAN}

Perusahaan Bali Honey yang dipimpin oleh Bapak Ismail, dapat disebut sebagai salah satu pakar usaha di bidang budidaya perlebahan di Indonesia. Ini dapat dibuktikan dengan waktu yang telah dilalui hingga saat ini telah mencapai 20 tahun lamanya. Madu pertama yang dihasilkan di panen dari atap rumah keluarga Ismail merupakan madu hasil dari koloni lebah Apis Cerana. Hasil panen pertama tersebut memberi semangat kepada Paman Ismail untuk belajar banyak mencintai lebah. Berbagai workshop dan pembinaan diikuti, termasuk dari Dinas Kehutanan. Pada tahun 1982 Paman Ismail mendapatkan hadiah satu koloni Apis Meliferra dari pemerintah Indonesia yang kemudian berkembang biak menjadi ratusan kotak.

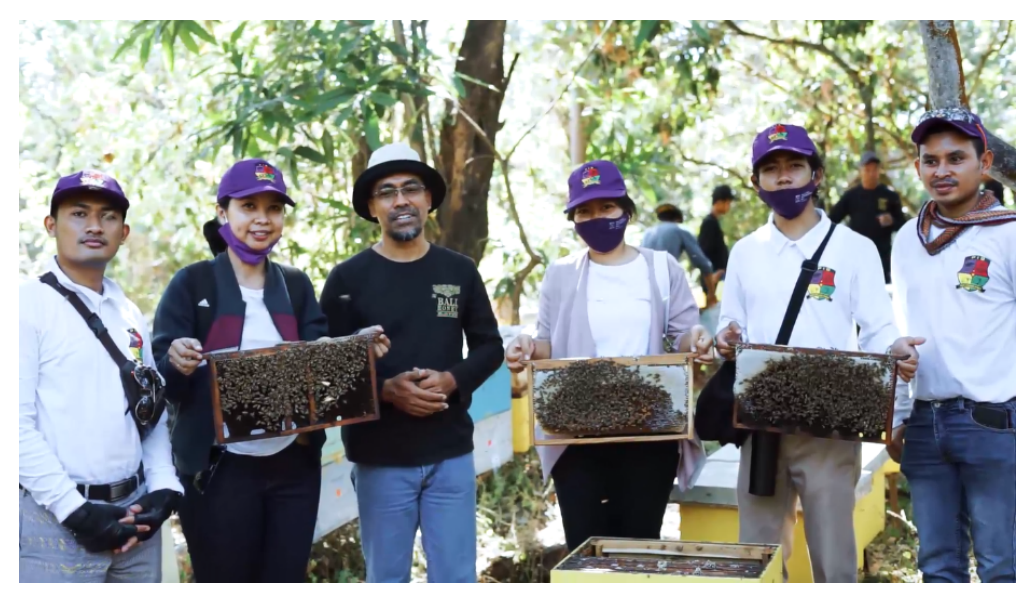

\section{Gambar 1. Koloni Apis Meliferra}

Lokasi di Desa Kubu, Tulamben, Karangasem, Juli 2020 
Adapun yang menjadi visi Bali Honey sebagai sebuah perusahaan madu di Indonesia yaitu ingin menjadi panutan penyedia produk perlebahan kwalitas terbaik dengan pola penanganan yang mengedepankan keseimbangan manusia dengan alam serta Fair Trade Business. Sedangkan misinya adalah dapat mengembangkan usaha produk perlebahan yang profesional dan terpercaya serta turut mendukung kelestarian ekosistem yang bermanfaat bagi kesehatan dan keseimbangan hidup dalam pola bisnis yang jujur. Nilai inti yang dijadikan pedoman Bali Honey yaitu jujur, tanggung jawab, visioner, disiplin, kerjasama, adil, dan peduli. Sebagai perusahaan keluarga, Bali Honey lebih mengedepankan pendekatan kekeluargaan, memperhatikan setiap detail dengan penuh cinta dan tanggung jawab. Dalam dekade ke 4 saat ini, Bali Honey telah memiliki 490 koloni lebah yang biasanya dibagi dalam 2 atau 3 lokasi gembala dibawah 3 supervisor lapangan yang dimiliki. Hasil panen rata-rata yang dihasilkan Bali Honey yaitu 1.2 ton madu per bulan. Menurut Ismail, madu yang dihasilkannya per bulan kurang progressive untuk sebuah bisnis, sehingga tim Bali Honey melakukan upaya untuk dapat meningkatkan kapasitas produksi sehingga dapat memenuhi kebutuhan yang ada. Salah satu upaya tersebut yaitu Bali Honey melakukan pembinaan berkala kepada peternak/pemelihara lebah lainnya dengan berpedoman pada prosedur standar yang dimiliki oleh Bali Honey. Sampai saat ini, Bali Honey telah berhasil membina 4 pemelihara lebah lainnya dengan standar mutu yang persis sama dengan Bali Honey sehingga akumulasi hasil panen keseluruhan bisa mencapai $6-8$ ton madu, $200 \mathrm{~kg}$ bee pollen $\& 8$ liter propolis per bulan. Tim Bali Honey bekerja untuk terus bisa berbagi pengalaman dan meningkatkan business value kepada rekan-rekan pemelihara lebah dan pencari madu hutan lainnya, sehingga bisnis bisa berkompetisi dan berkolaborasi dalam fair trade yang sehat. Saat ini Bali Honey dan rekan-rekan sedang mempersiapkan project pengelolaan madu dengan standar mutu ISO9001:2015. Tujuan sertifikasi ISO untuk menjamin produk yang dihasilkan perusahaan memenuhi persyaratan yang ditetapkan badan standar dunia yaitu ISO (International Organization for Standardization atau Organisasi Standar Internasional). Ketika perusahaan telah berhasil lulus audit dan mendapatkan ISO 9001 2015, artinya perusahaan tersebut telah memenuhi berbagai persyaratan yang telah ditetapkan secara internasional. Bila perusahaan dapat memenuhi kebutuhan konsumen secara spesifik, maka perusahaan bisa bertanggung jawab atas jaminan kualitas produk-produk yang dihasilkan.

Bali Honey dengan strategi usahanya berusaha untuk bersinergi dengan merangkul semua pihak mulai dari pemerintah sebagai penguasa hutan, petani komoditas, para ahli, stake holders dan pencari madu serta pemelihara lebah sampai pebisnis korporasi untuk menghasilkan dan memasarkan produk perlebahan Indonesia dengan standar mutu internasional yang mengutamakan untuk tetap melestarikan alam, memastikan harga madu di pasaran terjangkau agar masyarakat luas dapat memenuhi gizi dan nutrisi keluarganya dengan madu dan produk perlebahan yang berkwalitas. Adapun tim manajemen inti Bali Honey, sebagai berikut: Founder: Ir. H. M. Hanafie, Manager: Ismail M. SE, Finance: 
Shanti AD, SE, S.Sos, MM, Veterinary: Drh. Deddy S, dan sebagai Senior Adviser: Dr. Angelia RD.

Upaya yang Dilakukan Perusahaan Bali Honey dalam Meningkatkan Kemampuan Kerja Peternak Madu di Masa Pandemi Covid-19 ; Kepulauan tropis Indonesia sudah terkenal dengan kekayaan alamnya semenjak berabad-abad silam dan saat ini tetap merupakan ekosistem terbaik bagi ribuan jenis flora dan fauna. Keragaman ini berkontribusi besar terhadap kelengkapan nutrisi nektar dari ribuan jenis bunga pada cuaca yang nyaman dalam perbedaan hamparan, karakter tanah serta ketinggian daratan dari permukaan laut. Manfaat tidak langsung dari usaha budidaya lebah madu diantaranya berupa peningkatan gizi masyarakat, menciptakan lapangan pekerjaan serta membantu penyerbukan tanaman hutan dan tanaman pertanian sehingga kelestarian hutan di Indonesia dapat terjaga serta produksi pertanian meningkat. Menciptakan lapangan pekerjaan merupakan fokus utama Bali Honey di masa pandemic ini, dikarenakan Bali Honey meyakini bahwa peluang kerja di bidang usaha lebah madu sangat besar dan akan berdampak pada pemenuhan gizi masyarakat serta sekaligus membantu kelestarian hutan Indonesia. Untuk memenuhi lapangan kerja yang ada, Bali Honey berusaha membuat standarisasi kemampuan kerja peternak madu untuk dapat menghasilkan kualitas hasil panen madu yang baik yaitu sesuai standar perusahaan Bali Honey sehingga mampu bersaing di pasaran. Bali Honey dalam meningkatkan kemampuan kerja para peternak madu secara konsisten melakukan kegiatan edukasi dan pelatihan tentang panen madu. Pelatihan dimaksudkan untuk membantu meningkatkan kemampuan kerja peternak lebah madu melaksanakan tugas sekarang, sedangkan pendidikan atau edukasi lebih berorientasi pada peningkatan produktivitas kerja pegawai di masa depan. Kegiatan ini dilakukan untuk mengedukasi para peternak madu agar memiliki kemampuan kerja yang sama satu dengan yang lain. Dalam kegiatan yang dilakukan tersebut, Bali Honey menggunakan teori Penguatan, teori Harapan, dan teori Penetapan Tujuan sebagai dasar dari aktivitas yang dilakukan. Hukum pengaruh merupakan inti dari teori penguatan, tingkah laku positif diberikan oleh Bali Honey dalam melakukan kegiatan edukasi kepada para pekerja peternak madu dilakukan secara konsisten (diulang). Bali Honey memberikan rangsangan berupa ilmu pengetahuan dan keterampilan/pelatihan bekerja dalam melakukan kegiatan panen madu secara langsung di lapangan yaitu dengan ikut terlibat langsung dalam kegiatan panen madu perusahaan. Pelatihan tersebut tidak berbayar (gratis). Tujuan dari pelaksanaan pelatihan yang akan terus konsisten dilakukan oleh Bali Honey yaitu untuk menjaga motivasi para peternak madu agar dapat bekerja dengan standar yang baik sehingga kualitas panen yang dihasilkan mampu bersaing di pasaran.

Untuk mendukung kegiatan edukasi dan pelatihan tersebut, Bali Honey melakukan pendekatan dengan menggunakan teori Harapan yaitu menekankan pada hasil kualitas panen madu. Teori ini menunjukkan bahwa kekuatan pada hasil panen madu akan dapat merangsang para pekerja untuk konsisten mengikuti edukasi dan pelatihan yang diberikan, sehingga upaya Bali Honey dalam meningkatkan kemampuan kerja peternak madu dapat terwujud. Harapan seorang peternak madu merupakan hal yang penting, karena dari harapan tersebut para pekerja mempunyai dorongan atau motivasi untuk mencapai harapannya sehingga 
kinerja yang diberikan pekerja akan lebih maksimal. Bali Honey dalam melakukan upayanya menetapkan tujuan untuk dapat melibatkan peternak lebah madu, petani buah dan bunga serta kalangan masyarakat umum dalam setiap kegiatan panen madu. Untuk itu dilakukan penyebaran informasi melalui sosial media seperti facebook, instagram dan google, serta informasi yang bersifat langsung dari mulut ke mulut. Tujuan yang lebih spesifik dapat menjadi sebuah dorongan internal bagi perusahaan sehingga kemampuan kerja peternak madu yang memiliki harapan sama dapat lebih spesifik meningkat. Tujuan ini akan dipertahankan oleh peternak madu yang ikut dalam kegiatan edukasi dan pelatihan yang diberikan, sehingga kemampuan kerja yang dimiliki akan lebih baik daripada rekan kerjanya yang tidak memiliki tujuan dan harapan khusus dalam pekerjaannya.

\begin{tabular}{|c|c|c|}
\hline \multicolumn{3}{|c|}{ Teori Penguat (Reinforcement Theory) } \\
\hline $\begin{array}{l}\text { Konsisten melakukan } \\
\text { kegiatan penyuluhan } \\
\text { dan pelatihan tentang } \\
\text { kegiatan panen madu. }\end{array}$ & $\begin{array}{l}\text { Rangsangan berupa ilmu } \\
\text { pengetahuan dan } \\
\text { pelatihan bekerja dalam } \\
\text { melakukan kegiatan } \\
\text { panen madu secara }\end{array}$ & $\begin{array}{l}\text { Menjaga motivasi para } \\
\text { peternak madu agar } \\
\text { dapat bekerja dengan } \\
\text { standar yang baik } \\
\text { sehingga kualitas panen }\end{array}$ \\
\hline \multicolumn{3}{|c|}{ Teori Harapan (Expectacy Theory) } \\
\hline $\begin{array}{l}\text { Menekankan pada hasil } \\
\text { kualitas panen madu } \\
\text { dengan pengelolaan } \\
\text { madu berstandar mutu } \\
\text { ISO9001:2015 }\end{array}$ & $\begin{array}{l}\text { Kekuatan pada hasil } \\
\text { panen madu yang } \\
\text { berkualitas dapat } \\
\text { merangsang para } \\
\text { pekerja untuk konsisten } \\
\text { mengikuti edukasi dan } \\
\text { pelatihan vang diberikan }\end{array}$ & $\begin{array}{l}\text { Standarisasi } \\
\text { kemampuan kerja } \\
\text { menghasilkan kualitas } \\
\text { hasil panen madu yang } \\
\text { baik sehingga mampu } \\
\text { bersaing di pasaran }\end{array}$ \\
\hline \multicolumn{3}{|c|}{ Teori Penetapan Tujuan (Goal Setting Theory) } \\
\hline $\begin{array}{l}\text { Kemampuan kerja yang } \\
\text { dimiliki akan lebih baik } \\
\text { daripada rekan kerjanya } \\
\text { yang tidak memiliki } \\
\text { tujuan dan harapan } \\
\text { khusus dalam } \\
\text { pekerjaannya }\end{array}$ & $\begin{array}{l}\text { Melibatkan peternak } \\
\text { madu, petani buah dan } \\
\text { bunga, serta masyarakat } \\
\text { umum dalam setiap } \\
\text { kegiatan panen madu. }\end{array}$ & $\begin{array}{l}\text { Kejelasan tujuan akan } \\
\text { menumbuhkan motivasi } \\
\text { yang tinggi, dapat } \\
\text { membuat kemampuan } \\
\text { kerja meningkat }\end{array}$ \\
\hline
\end{tabular}

\section{Gambar 2. Penerapan Teori Penguat, Teori Harapan dan Teori Penetapan Tujuan}


Selain dapat diikuti oleh para peternak madu, kegiatan edukasi dan pelatihan yang diberikan oeh Bali Honey dapat diikuti oleh petani buah dan bunga, serta masyarakat umum, khususnya masyarakat yang tinggal di sekitar area panen. Bali Honey berharap dapat terjalin kerjasama yang baik di antara peternak lebah madu dengan petani buah dan bunga juga masyarakat melalui kegiatan yang dilaksanakan. Petani buah dan bunga diharapkan tidak lagi memiliki pemikiran bahwa hasil panen dapat menurun atau rusak dikarenakan lebah madu yang mendatangi area ladang atau kebun mereka untuk mencari makan dengan menghisap sari bunga tanaman. Sedangkan manfaat yang diperoleh oleh masyarakat umum yaitu mengetahui aktivitas panen madu secara langsung di area panen madu yang dilakukan oleh para peternak lebah.

Kejelasan tujuan yang hendak dicapai oleh seseorang dalam melaksanakan tugasnya akan menumbuhkan motivasi yang tinggi. Tujuan yang sulit sekalipun apabila ditetapkan sendiri oleh orang yang bersangkutan atau organisasi yang membawahinya akan membuat prestasi meningkat, asalkan dapat diterima sebagai tujuan yang pantas dan layak dicapai. Dari tiga teori di atas, dapat disimpulkan bahwa motivasi adalah suatu keinginan dari dalam diri manusia atau individu yang dapat dipengaruhi dari dalam diri ataupun dari luar diri manusia itu sendiri, yang dapat mempengaruhinya baik secara positif ataupun secara negatif, tergantung pada kondisi manusia atau individu tersebut.

Strategi Yang Dilakukan Untuk Meningkatkan Kualitas Hasil Panen Madu Agar Dapat Membawa Manfaat Bagi Peternak Madu, Pemilik Kebun Dan Masyarakat Setempat; Kebanyakan pencari madu dan pemelihara lebah belum menjalankan usahanya dengan bijak dan profesional sehingga quantitas dan qualitas madu yang dipasarkan tidak konsisten. Hal ini diperburuk dengan berkurangnya kuantitas flora Indonesia dan tingginya pemakaian bahan kimia yang berdampak pada harga madu makin tinggi yang ahirnya membuka peluang beredarnya madu dengan mutu rendah. Konsumsi madu dan produk perlebahan di Indonesia menjadi sangat rendah. Disisi lain, pengetahuan konsumen tentang madu juga minim sehingga mudah mempercayai mitos dan pendapat non ilmiah. Kegiatan budidaya lebah madu oleh Bali Honey dimulai dari pemeliharaan dan perawatan, pemanenan, pengemasan, hingga pemasaran. Rangkaian kegiatan tersebut mempunyai teknik sehingga membutuhkan keahlian tersendiri. Farida (2000) mengungkap bahwa selain lahan dan modal, usaha budidaya lebah madu memerlukan tenaga kerja, pengetahuan, keterampilan, dan manajemen yang baik. Bali Honey dalam perannya meningkatkan kualitas hasil panen madu memiliki alternatif strategi yang dapat diterapkan oleh para peternak madu yang mengikuti kegiatan edukasi dan pelatihan.

Adapun strategi dalam meningkatkan kualitas hasil panen madu yang dapat diterapkan, antara lain dengan memberikan pemahaman kepada seluruh komponen yang terlibat dalam kegiatan panen madu khususnya peternak lebah madu dan petani buah dan bunga, juga edukasi yang bersifat umum yang ditujukan kepada masyarakat umum yang ikut dalam kegiatan edukasi dan pelatihan Bali Honey. Karena sampai dengan saat ini, masih ada komponen masyarakat dari petani buah dan bunga yang menolak untuk bekerja sama karena belum sepenuhnya percaya pada manfaat yang akan diperoleh. Ismail mengatakan 
"bahwa tujuan dari kegiatan yang dilakukan Bali Honey yaitu terwujudnya sinergi antara petani buah dan bunga dengan peternak lebah madu. Tidak ada lagi pemikiran bahwa lebah madu yang dilepaskan di area ladang atau kebun petani dapat menyebabkan rusaknya hasil panen sehingga kuantitas dan kualitas panen menurun. Justru kegiatan panen madu yang dilakukan memberikan manfaat yang baik bagi para petani buah dan bunga yaitu lebah madu membantu proses penyerbukan serbuk sari pada tanaman sehingga kualitas hasil panen meningkat', dan peternak madu akan menghasilkan madu yang baik karena lebah madu mendapatkan makanannya dari sari bunga yang dimiliki petani buah dan bunga. Untuk meminimalkan dan meniadakan persepsi yang tidak benar tersebut harus dilakukan penyuluhan dengan baik dan rutin kepada masyarakat luas, sehingga masyarakat dapat memahami dengan baik bahwa kerjasama yang dilakukan betulbetul akan bersinergi dan menghasilkan kualitas yang baik bagi hasil panen kedua belah pihak.

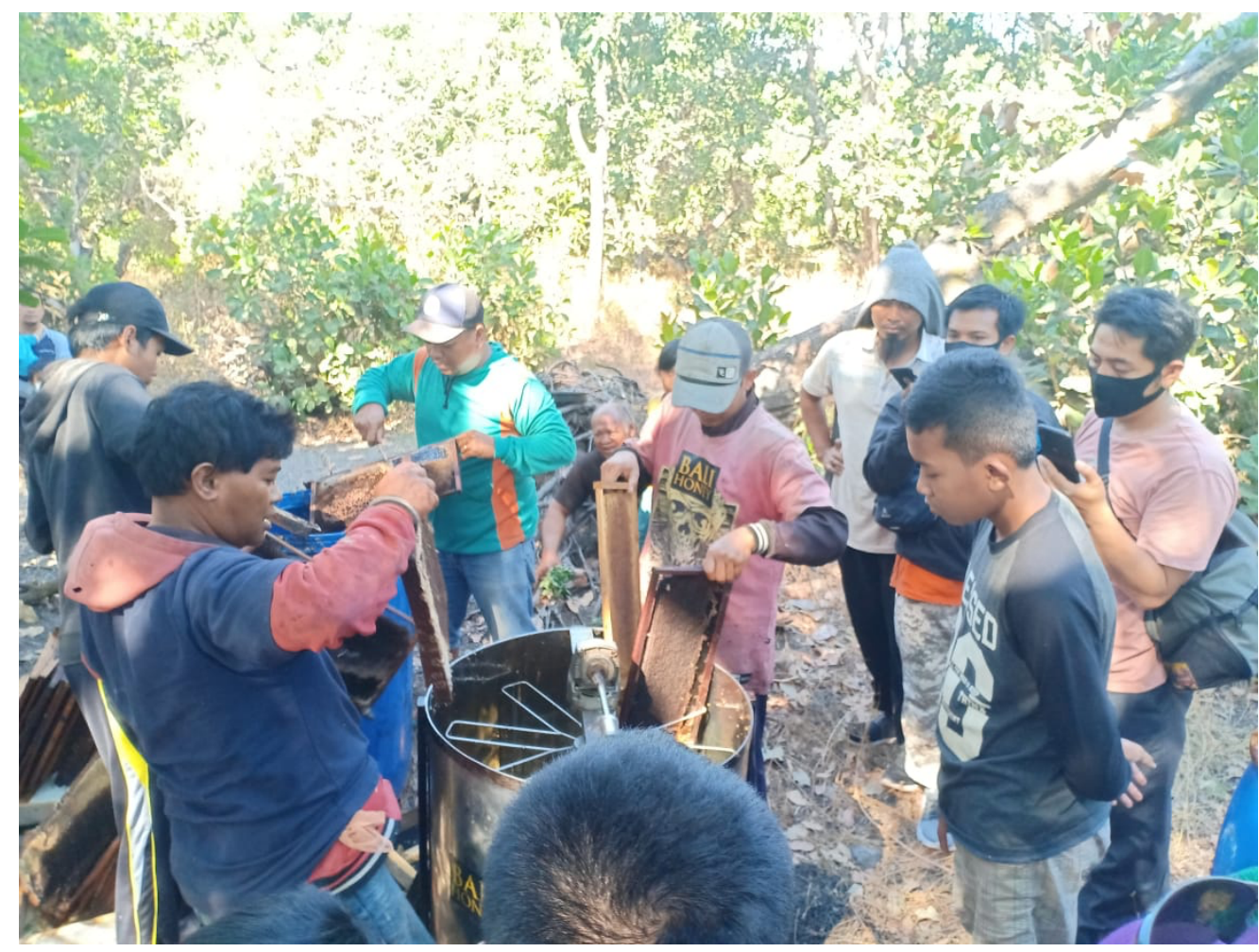

Gambar 3. Kegiatan Panen Madu

Lokasi di Desa Kubu, Tulamben, Karangasem, Juli 2020

Selain pemahaman yang diberikan secara langsung saat kegiatan panen madu, Ismail juga melakukan edukasi secara konsisten melalui gerai offline yang dimilikinya, pelanggan yang datang diberikan penjelasan tentang madu dengan baik sehingga pelanggan dapat mengerti tentang manfaat madu, kualitas madu yang baik untuk dikonsumsi, dan tak kalah pentingnya adalah terkait harga madu. 
Ismail mengatakan bahwa harga menjadi salah satu faktor yang menjadi pertimbangan masyarakat dalam membeli madu. Tidak jarang masyarakat memutuskan untuk membeli madu karena harganya murah, tanpa mengetahui kualitas dari madu yang dibeli. Jadi menurut Ismail, harga juga menentukan kualitas. Selain harga, yang menjadi pertimbangan lainnya yaitu masyarakat harus jeli dan pintar dalam berbelanja. Selaku konsumen, minimal harus mencari informasi tempat dimana akan berbelanja, seperti apa ruang lingkup usahanya, dan bila memungkinkan sebaiknya konsumen dapat datang langsung ke gerai madu secara langsung. Bila penjual madu tidak memiliki gerai offline, dapat dilihat dari aktivitas media sosial yang dimiliki dan hasil interaksi yang ada antara si penjual dengan konsumen.

Strategi lain yang dilakukan Bali Honey yaitu memberikan pengajaran dan pemahaman terkait teknik pemeliharaan dan perawatan komponen yang penting dalam pemeliharaan lebah yaitu pemeliharaan peralatan dan pakan lebah (beeforage), serta teknik pemanenan. Dan sebagai tambahan pengetahuan juga diberikan edukasi terkait teknik pengemasan madu. Dari segi peralatan, cara tradisional seperti menggunakan glodok telah diubah dalam bentuk stup atau kotak. Ukurannya dibuat berdasarkan prinsip detail rancang bangun, sedangkan untuk bahan dan gaya menyesuaikan, tergantung kreativitas. Untuk penempatan stup, diletakkan di tempat yang teduh. Kondisi keamanan stup dari gangguan semut maupun pengganggu lainnya seperti ngengat juga harus diperhatikan. Serangga yang biasanya menyerang lebah madu yaitu ngengat, tungau, semut, tabuhan vespa, dan tawon endas. Karena itu, peternak harus rajin memeriksa, menjaga, dan membersihkan bagian-bagian stup sehingga semut atau serangga lainnya tidak masuk. Selain itu, peralatan-peralatan pembantu lainnya juga diperlukan seperti masker, pisau, sikat lebah, tempat air, dan ekstaktor. Dari segi pakan lebah (beeforage), termasuk semua jenis tanaman berbunga, yaitu tanaman hutan, tanaman pertanian, tanaman perkebunan, maupun tanaman liar lainnya yang mengandung unsur-unsur nektar (madu), tepung sari (pollen), ekstrafloral, dan propolis. Di sekitar lokasi budidaya lebah juga harus dipastikan bahwa ketersediaan pakan cukup bagus sehingga memudahkan lebah untuk mencari makan.

Selain untuk tujuan meningkatkan kualitas hasil panen, pemeliharaan lebah madu juga dilakukan untuk tujuan produksi (panen). Teknik pemanenan pengecekan stup dilakukan tiap dua minggu. Apabila stup sudah penuh maka proses pemanenan bisa dilakukan. Ciri-ciri madu siap dipanen adalah sisiran telah tertutup oleh lapisan lilin tipis. Sisiran yang akan dipanen dibersihkan dulu dari lebah yang masih menempel kemudian lapisan penutup sisiran dikupas, lalu madu akan keluar dengan sendirinya. Cara pemanenan lebah madu dilakukan dengan cara manual sebagai berikut : (1) Asapkan kawasan kotak koloni (stup) agar dapat menghalau lebah madu ketika mengambil hasil. Pastikan memakai pakaian yang sesuai serta memakai jaring pelindung muka. (2) Angkat sisiran dari kotak koloni lebah menggunakan pengungkit sisiran. Ratu lebah harus dipindahkan terlebih dahulu ke stup lain. (3) Gunakan sikat sekiranya masih ada lebah yang masih tertinggal/melekat pada sisiran. (4) Setelah sisiran bebas dari lebah, maka sisiran dipotong menggunakan pisau. Sisiran dibersihkan terlebih dahulu dari lebah yang 
masih menempel (dipisahkan), lalu lapisan penutup sisiran dikupas dengan pisau yang telah direndam dengan air hangat. (5) Sisiran yang telah dipotong dipindahkan ketempat yang lain. Selanjutnya sisiran dimasukkan ke ekstraktor dan diputar secara perlahan agar anakan tidak ikut terjatuh. Setelah itu, madu hasil perasan disaring dengan menggunakan kain kasa dan dimasukkan ke dalam botol kemasan dan ditutup rapat. Untuk penyimpanan, dilakukan di tempat yang kering, bersih, dan tidak berbau.

Setelah proses pemanenan, para peternak madu juga diberikan edukasi tentang teknik pengemasan madu yang dijual oleh Bali Honey sesuai dengan jenis nektar bunganya, tidak menggunakan bahan pengawet, bahan perasa, maupun bahan pewarna apapun. Menurut Pratiwi (2010), pada dasarnya madu murni memiliki ketahanan yang tinggi terhadap kerusakan. Pendapat tersebut dibenarkan oleh Ismail selaku Direktur Bali Honey, bahwa Bali Honey mampu menciptakan loyalitas pada konsumen melalui produksi madu murni dengan citarasa alami yang berasal dari nektar. Selain itu, didukung oleh teknik pengemasan yang dilakukan Bali Honey telah dilakukan dengan cara hygienis dengan memperhatikan aturan protocol kesehatan yang ditetapkan pemerintah di masa pandemi ini.

Bali Honey dalam meningkatkan kemampuan kerja para peternak madu secara konsisten melakukan kegiatan penyuluhan dan pelatihan tentang kegiatan panen madu. Kegiatan ini dilakukan untuk mengedukasi para peternak madu agar memiliki kemampuan kerja yang sama satu dengan yang lain. Dalam kegiatan yang dilakukan tersebut, Bali Honey menggunakan teori Penguatan, teori Harapan, dan teori Penetapan Tujuan sebagai dasar dari aktivitas yang dilakukan.

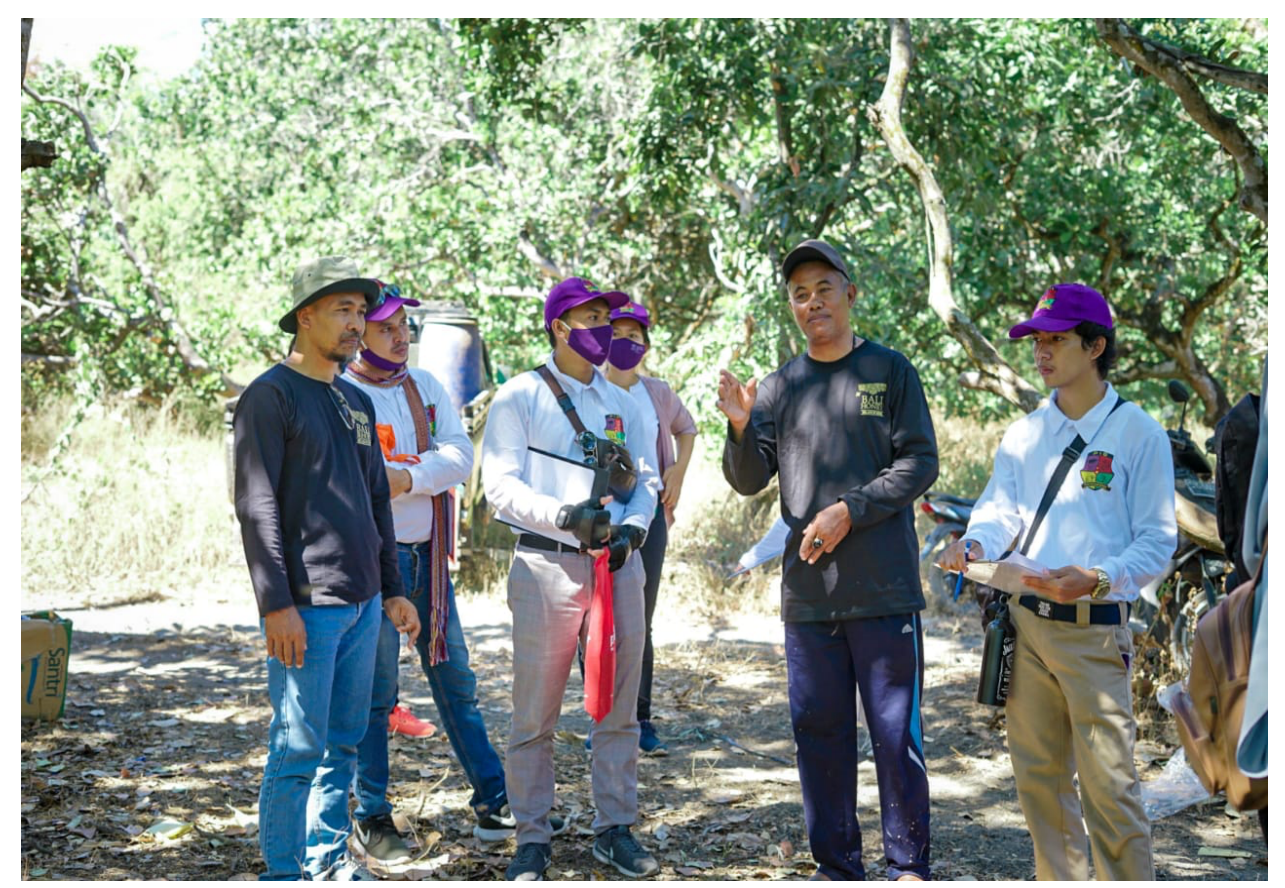

\section{Gambar 4. Kegiatan Penyuluhan}

Lokasi di Desa Kubu, Tulamben, Karangasem, Juli 2020 


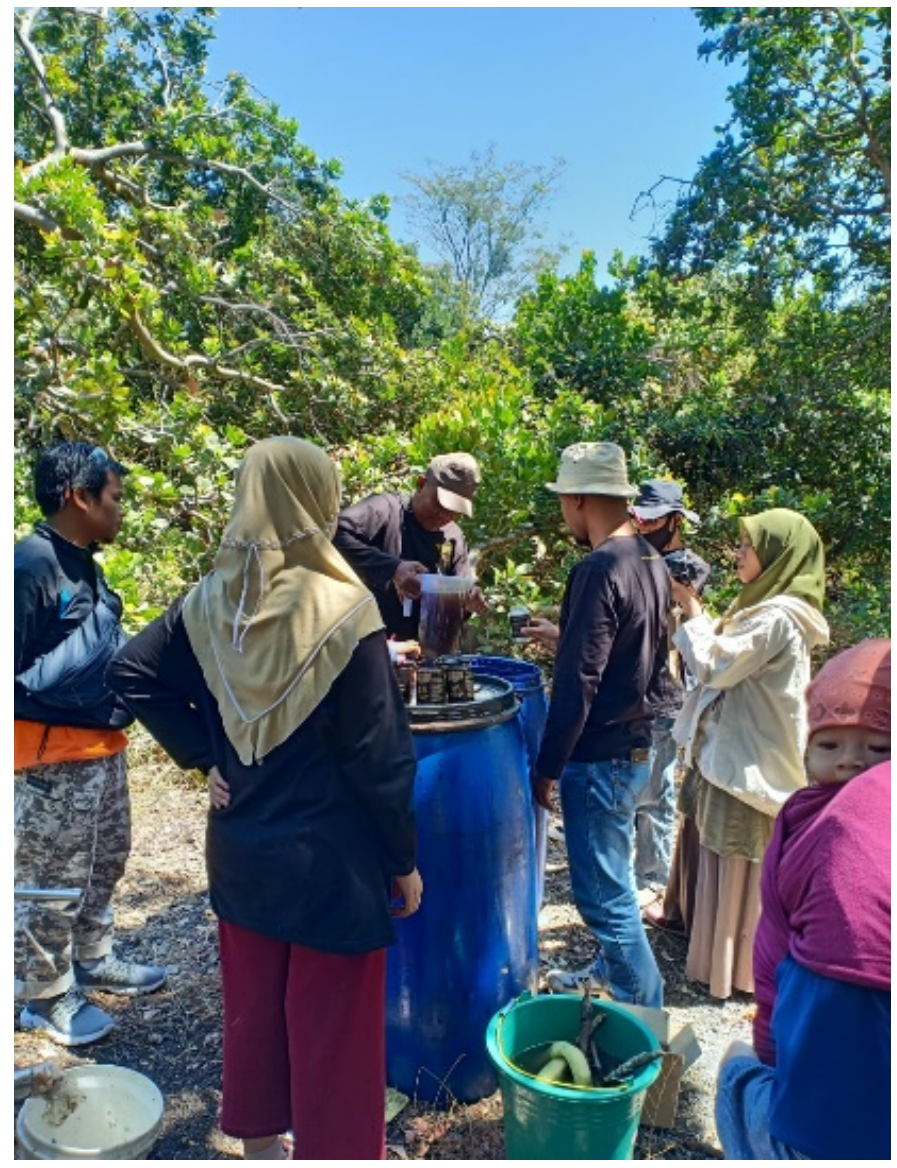

\section{Gambar 5. Kegiatan Penyuluhan}

Lokasi di Desa Kubu, Tulamben, Karangasem, Juli 2020

Teori Penguat didasarkan atas "hukum pengaruh". Tingkah laku dengan konsekuensi yang positif cenderung dilakukan berulang, sedangkan tingkah laku dengan konsekuensi negatif cenderung tidak dilakukan berulang. Rangsangan yang dihasilkan menumbuhkan motivasi yang dapat berupa timbulnya respon dari seseorang, dimana selanjutnya akan menghasilkan suatu konsekuensi yang dapat berpengaruh pada tindakan selanjutnya. Konsekuensi yang terjadi secara berulang dan berlanjut terus-menerus akan menjadi suatu bentuk rangsangan yang perlu untuk direspon kembali sehingga menghasilkan konsekuensi. Demikian seterusnya sehingga motivasi peternak madu dapat tetap terjaga untuk menghasilkan hal-hal yang positif. Hukum pengaruh merupakan inti dari teori penguatan, tingkah laku positif diberikan oleh Bali Honey dalam melakukan kegiatan edukasi kepada para pekerja peternak madu dilakukan secara konsisten (diulang). Bali Honey memberikan rangsangan berupa ilmu pengetahuan dan keterampilan/pelatihan bekerja dalam melakukan kegiatan panen madu secara langsung di lapangan yaitu dengan ikut terlibat langsung dalam kegiatan panen madu perusahaan. Pelatihan tersebut tidak berbayar (gratis). Tujuan dari pelaksanaan pelatihan yang akan terus konsisten dilakukan oleh Bali Honey yaitu 
untuk menjaga motivasi para peternak madu agar dapat bekerja dengan standar yang baik sehingga kualitas panen yang dihasilkan mampu bersaing di pasaran.

Untuk mendukung kegiatan edukasi dan pelatihan tersebut, Bali Honey melakukan pendekatan dengan menggunakan teori Harapan yaitu menekankan pada hasil kualitas panen madu. Teori Harapan menunjukkan bahwa kekuatan dari suatu kecenderungan untuk bertindak dalam cara tertentu bergantung pada kekuatan dari suatu harapan bahwa tindakan tersebut akan diikuti dengan hasil yang ada dan pada daya tarik dari hasil itu terhadap individu tersebut. Teori ini berusaha agar setiap pekerja mau bekerja giat sesuai dengan harapan. Daya pendorong yang mampu memotivasi semangat kerja terkandung dari harapan yang akan diperoleh para pekerja. Pekerja cenderung akan meningkatkan kualitas kerjanya, jika harapan menjadi kenyataan, maka begitu pula sebaliknya. Teori ini menunjukkan bahwa kekuatan pada hasil panen madu akan dapat merangsang para pekerja untuk konsisten mengikuti edukasi dan pelatihan yang diberikan, sehingga upaya Bali Honey dalam meningkatkan kemampuan kerja peternak madu dapat terwujud. Harapan seorang peternak madu merupakan hal yang penting, karena dari harapan tersebut para pekerja mempunyai dorongan atau motivasi untuk mencapai harapannya sehingga kinerja yang diberikan pekerja akan lebih maksimal.

Bali Honey dalam melakukan upayanya tersebut menggunakan teori Penetapan Tujuan menyebutkan bahwa perilaku individu diatur oleh pemikiran (ide) dan niat seseorang. Sasaran dapat dipandang sebagai tujuan atau tingkat kerja yang ingin dicapai oleh individu. Sumber motivasi kerja yang utama berupa niat untuk mencapai sebuah tujuan, yang artinya seorang karyawan telah mengerti tujuan yang igin dicapai, mengerti apa yang harus dilakukan dan besarnya usaha yang harus dikeluarkan untuk mencapai tujuan yang ditetapkan. Kesimpulannya, bahwa penetapan suatu tujuan tidak hanya berpengaruh terhadap pekerjaan saja, tetapi juga mempengaruhi orang tersebut untuk mencari cara yang efektif dalam mengerjakannya. Seseorang dalam melaksanakan tugasnya harus mengetahui kejelasan tujuan yang hendak dicapai untuk dapat menumbuhkan motivasi yang tinggi pada diri. Bali Honey menetapkan tujuan untuk mendapatkan minimal sebanyak 15 orang peternak madu terlibat dalam setiap kegiatan panen madu. Tujuan yang lebih spesifik dapat menjadi sebuah dorongan internal bagi perusahaan sehingga kemampuan kerja peternak madu yang memiliki harapan sama dapat lebih spesifik meningkat. Tujuan ini akan dipertahankan oleh peternak madu yang ikut dalam kegiatan edukasi dan pelatihan yang diberikan, sehingga kemampuan kerja yang dimiliki akan lebih baik daripada rekan kerjanya yang tidak memiliki tujuan dan harapan khusus dalam pekerjaannya.

Motivasi yang tinggi akan dimiliki oleh seseorang apabila orang tersebut memiliki kejelasan akan tujuan yang hendak dicapai. Tujuan yang sulit sekalipun apabila ditetapkan sendiri oleh orang yang bersangkutan atau organisasi yang membawahinya akan membuat prestasi yang meningkatkan, asalkan dapat diterima sebagai tujuan yang pantas dan layak dicapai. Dari tiga teori di atas, dapat disimpulkan bahwa motivasi adalah suatu keinginan dari dalam diri manusia atau individu yang dapat dipengaruhi dari dalam diri manusia itu sendiri atau 
berasal dari luar, yang dapat mempengaruhinya baik secara positif ataupun secara negatif, tergantung pada kondisi manusia atau individu tersebut.

\section{SIMPULAN}

Bali Honey menggunakan teori penguatan berupa rangsangan ilmu pengetahuan dan keterampilan/pelatihan bekerja dalam melakukan kegiatan panen madu secara langsung di lapangan yaitu dengan ikut terlibat langsung dalam kegiatan panen madu perusahaan. Pelatihan tersebut tidak berbayar (gratis). Untuk mendukung kegiatan edukasi dan pelatihan tersebut, Bali Honey melakukan pendekatan dengan menggunakan teori Harapan yaitu menekankan pada hasil kualitas panen madu. Teori ini menunjukkan bahwa kekuatan pada hasil panen madu akan dapat merangsang para pekerja untuk konsisten mengikuti edukasi dan pelatihan yang diberikan, sehingga upaya Bali Honey dalam meningkatkan kemampuan kerja peternak madu dapat terwujud. Bali Honey dalam melakukan upayanya tersebut menetapkan tujuan untuk mendapatkan minimal sebanyak 15 orang peternak madu terlibat dalam setiap kegiatan panen madu. Tujuan yang lebih spesifik dapat menjadi sebuah dorongan internal bagi perusahaan sehingga kemampuan kerja peternak madu yang memiliki harapan sama dapat lebih spesifik meningkat. Tujuan ini akan dipertahankan oleh peternak madu yang ikut dalam kegiatan edukasi dan pelatihan yang diberikan, sehingga kemampuan kerja yang dimiliki akan lebih baik daripada rekan kerjanya yang tidak memiliki tujuan dan harapan khusus dalam pekerjaannya.

Kegiatan budidaya lebah madu oleh Bali Honey dimulai dari pemeliharaan dan perawatan, pemanenan, pengemasan, hingga pemasaran. Rangkaian kegiatan tersebut mempunyai teknik sehingga membutuhkan keahlian tersendiri. Usaha beternak lebah madu selain membutuhkan lahan dan modal, juga membutuhkan SDM, pengetahuan, keterampilan, dan manajemen yang baik. (Farida, 2000). Bali Honey dalam perannya meningkatkan kualitas hasil panen madu memiliki alternatif strategi yang dapat diterapkan oleh para peternak madu yang mengikuti kegiatan edukasi dan pelatihan. Adapun strategi dalam meningkatkan kualitas hasil panen madu yang dapat diterapkan, antara lain dengan memberikan pemahaman kepada seluruh peternak madu yang ikut dalam kegiatan edukasi dan pelatihan Bali Honey, mengenai seluruh teknik dari tahap awal berupa pemeliharaan dan perawatan komponen penting dalam pemeliharaan lebah yaitu peralatan dan pakan lebah (beeforage), pemanenan, sampai dengan edukasi terkait teknik pengemasan madu.

Peningkatan produktivitas usaha perlebahan dapat dilakukan melalui peningkatan kemampuan kerja para peternak. Kemampuan kerja merupakan suatu cara pandang seseorang yang bersifat positif maupun negatif tentang pekerjaannya. Yang sudah barang tentu akan mempengaruhi kualitas hasil kerja dalam hal ini kualitas hasil panen madu. Kemampuan kerja dapat ditingkatkan dengan menambah pengalaman langsung di lapangan dalam beternak lebah madu. Demikian pula dengan tenaga kerja, makin banyak curahan tenaga peternak, akan makin meningkatkan produktivitas usaha ternak lebah madu yang dihasilkan. Salah satu aspek dalam meningkatkan kemampuan kerja SDM yaitu melalui 
pemberian motivasi (daya perangsang) kepada peternak madu, dengan istilah populer sekarang pemberian kegairahan bekerja kepada karyawan. Motivasi yang dimaksud salah satunya dapat berupa kegiatan edukasi dan pelatihan secara konsisten dan terarah, yang diberikan secara gratis seperti yang dilakukan oleh perusahaan madu Bali Honey.

Karena peningkatan produktivitas usaha ternak lebah madu dapat dilakukan melalui peningkatan kemampuan kerja, maka disarankan kepada para peternak lebah madu agar terus berusaha meningkatkan kemampuan kerja yang dimiliki. Kemampuan kerja merupakan suatu cara pandang seseorang yang bersifat positif maupun negatif tentang pekerjaannya, yang sudah barang tentu akan mempengaruhi kualitas hasil kerja dalam hal ini kualitas hasil panen madu. Selain itu produksi lebah madu dapat pula ditingkatkan melalui penambahan pengalaman beternak lebah madu, karena semakin banyak pengalaman akan semakin terampil para peternak dalam beternak lebah madu. Demikian pula dengan tenaga kerja, makin banyak curahan tenaga peternak, akan makin meningkatkan produktivitas usaha ternak lebah madu yang dihasilkan. Salah satu aspek dalam meningkatkan kemampuan kerja SDM yaitu melalui pemberian motivasi (daya perangsang) kepada peternak madu, dengan istilah populer sekarang pemberian kegairahan bekerja kepada karyawan. Usaha untuk merealisasi kemungkinan tersebut ialah dengan jalan memberikan motivasi. Motivasi ini dimaksudkan untuk memberikan daya perangsang kepada karyawan yang bersangkutan agar karyawan tersebut bekerja dengan segala daya dan upayanya (Manulang, 2002). Motivasi yang dimaksud salah satunya dapat berupa kegiatan edukasi dan pelatihan secara konsisten dan terarah, yang diberikan secara gratis seperti yang dilakukan oleh perusahaan madu Bali Honey. Sedangkan bagi petani buah dan bunga diharapkan berkomitmen dalam bekerjasama dengan para peternak lebah madu. Menghilangkan prasangka yang mengatakan bahwa lebah madu dapat merusak hasil panen yang dihasilkan. Ikut berkontribusi dalam menyebarkan informasi terkait kerjasama yang dilakukan, sehingga tidak terjadi penolakan oleh petani buah dan bunga akan kedatangan para peternak lebah madu dikemudian hari. Kepada masyarakat umum dapat disampaikan agar lebih peka terhadap kualitas madu yang baik, sehingga dapat menekan beredarnya madu dengan kualitas yang tidak sesuai dengan standar, dapat menjaga kestabilan harga madu di pasaran, dan memberikan manfaat maksimal kepada masyarakat yang mengkonsumsi madu.

\section{REFERENSI}

Alma, B. H. (2018). Manajemen Pemasaran \& Pemasaran Jasa. Bandung: Alfabeta.

Farida, I. (2000). Evaluasi Perkembangan Usaha Lebah Madu Apis mellifera (Studi Kasus pada Perusahaan Industri Kecil Madu Odeng Cibubur Jakarta). IPB.

Kamizal, I. (2015). Analisis Pengaruh Kualitas Bahan Ajar Dan Kualitas Metode Pengajaran Yang Digunakan Trainer Pada Pelatihan Anzen Leader Terhadap Peningkatan Kinerja Anzen Leader (Studi Kasus Pt Toyota Motor Manufacturing Indonesia). In Jurnal Ilmiah Universitas Bakrie. 
Kotler dan Keller. (2017). Manajemen Pemasaran, Edisi 12, Jilid 1, PT.Indeks,. Jakarta. In e-Jurnal Riset Manajemen.

Kotler, P., \& Gary Amstrong. (2018). Prinsip-prinsip.Pemasaran 1. Edisi Keduabelas. Jakarta: Erlangga.

Nasution, M. N. D. (2005). Manajemen mutu terpadu (edisi 2). Bogor: Ghalia Indonesia.

Robbins, S., \& Judge, T. (2008). Perilaku Organisasi. Jakarta: PT. Salemba Empat.

Simamora, H. (2006). Manajemen Sumber Daya Manusia (Edisi 3).

Soekartiko, B. (2000). Permasalahan dalam Usaha Perlebahan di Indonesia.Prosiding Temu Usaha Perlebahan. Jakarta: Direktorat Jenderal Rehabilitasi Lahan dan Perhutanan Sosial, Departemen Kehutanan; Perum Perhutani; API Indonesia.

Sugiyono. (2017). Metode Penelitian Bisnis (Pendekatan Kuantitatif, Kualitatif, Kombinasi dan R\&DSugiyono. (2017). Metode Penelitian Bisnis (Pendekatan Kuantitatif, Kualitatif, Kombinasi dan R\&D). In Metodelogi Penelitian.). In Metodelogi Penelitian.

Tjiptono, F. (2015). Strategi Pemasaran, Edisi 4. Andi, Yogyakarta. 